\title{
Uncommon Glomus Tumor at The Volar Area of Distal Phalang: a Case Report
}

\author{
Wahyu Widodo, Aryo Nugroho Triyudanto \\ Department of Orthopaedic and Traumatology Cipto Mangunkusumo Hospital/Faculty of Medicine University of Indonesia, Jakarta, Indonesia
}

Diterima: 10 Februari 2017; Direview: 13Februari 2017; Disetujui: 27 Februari 2017

\author{
KORESPONDENSI: \\ dr. Wahyu Widodo, SpOT (K) \\ Department of Orthopaedic \\ \& Traumatology \\ Cipto Mangunkusumo \\ National Central Hospital \\ - Faculty of Medicine \\ Universitas Indonesia, \\ Jl. Diponegoro No. 71, \\ Jakarta, Indonesia. \\ $+6281514169848$ \\ Fax: +62213905894 \\ Email: \\ wawidfkui@yahoo.com
}

\begin{abstract}
Introduction: Glomus tumor, a benign rare neoplasmic perivascular lesion arising from glomus neuromial-arterial tissue. Glomus cells, which are found in the dermis throughout the body, are responsible for thermoregulation. In this tumor, its cells proliferate and surround the vascular canals, producing a classic clinical sign such as spontaneous pain, pain on light touching, and temperature hyperesthesia. Despite its rare occurrence, it is necessary to know how recognize and treat this variant of perionychium tumor.

Case Illustration: A forty-seven-year old woman came with pain on the tip of her ring finger since 3 years before admission. Over time, the tingling sensation worsened and eventually pain emerged. The appearance of her ring finger and nail were normal. However, the patient felt pain after a light touch and paresthesia especially at the volar side of her ring finger. Having normal radiograph appearance, excisional biopsy was then performed. Histologic examination showed a well-defined lesion encapsulated by a fibrous capsule. The lesion consisted of several thin-walled flared vascular containments with layers of glomus cells around it, which is in accordance with characteristic of benign glomus tumor.At the latest follow up, there were no complication or recurrence found. The pain and paresthesia around the ring finger were also diminished.

Conclusion: Despite its rare occurrence, the diagnosis of Glomus Tumor can be performed clinically. Excisional biopsy is the definitive treatment and specific diagnostic modality for Glomus Tumor.
\end{abstract}

Keywords: Glomus, perionychium tumor, distal phalang, biopsy..

\section{ABSTRAK}

Glomus tumor adalah tumor jaringan lunak yang cukup jarang ditemui dan merupakan lesi perivaskular yang muncul dari arteri glomus neuromial. Sel glomus berproliferasi dan mengelilingi kanal vaskular. Tumor ini sering ditemukan pada area subungual. Tanda khasnya adalah nyeri spontan, nyeri pada sentuhan ringan, dan sensitivitas terhadap suhu. Kemampuan mengenali dan mengobati tumor perionychium ini penting.

Wanita usia 47 tahun datang dengan keluhan utama nyeri pada jari manis sejak 3 tahun lalu. Seiring waktu, sensasi kesemutan dan nyeri memburuk. Pada pemeriksaan fisik di regio distal phalang tidak ditemukan bengkak dan kemerahan, deformitas, atau massa. Kulit intak tanpa perubahan warna dengan sekitar. Kuku tampak normal. Pada palpasi didapatkan nyeri pada sentuhan ringan di area volar dengan VAS 4-5 dan paresthesia pada sisi volar. Pemeriksaan x-ray menunjukkan hasil normal. Pada pemeriksaan biopsi eksisional dan pemeriksaan histopatologi ditemukan lesi berbatas tegas yang terdiri atas kapsula fibrosa dengan beberapa lapis dinding dan vaskular serta sel glomus yang menutupinya. Tiga bulan pasca-operasi tidak ditemukan nyeri dan paresthesia pada lokasi tumor. Tumor glomus adalah tumor yang jarang dan dapat didiagnosis melalui tampilan klinis. Biopsi eksisional merupakan pengobatan definit, sekaligus modalitas diagnostik spesifik.

Kata Kunci: glomus, perionychium tumor, distal phalang, biopsi 
G lomus tumor, a rare occurrence, is described as benign perivascular neoplastic lesion that arises from neuromyoarterial glomus, where its cells proliferated and surround the vascular canals. The most common site of glomus tumor is in subungual area. Classic symptoms include spontaneous pain, pain on light touch, and temperature hyperesthesia. ${ }^{1}$ The diagnosis for glomus tumor are usually based on clinical finding, but may be supported with other modalities, such as ultrasound and magnetic resonance imaging (MRI)., ${ }^{2,3}$

Tumor excisional biopsy is the most preferred and the most cost-efficient treatment for glomus tumor. ${ }^{4}$ Glomus tumor has good prognosis if complete removal is achieved. However, recurrence might occur if excisional biopsy is incomplete and multiple lesions are left undetected. ${ }^{5}$ Histopathology findings of glomus tumor, as reported by Peretz et $\mathrm{al}^{6}{ }^{6}$ showed well-defined lesion surrounded by fibrous cap that consisted of several thin-walled vascular spaces that stretched and surrounded by layers of glomus cells. Despite the majority of glomus tumor cases are benign, several reports since 1996 has documented its metastatis. ${ }^{7}$ Malignant glomus tumor is characterized by profound location, size bigger than $2 \mathrm{~cm}$, or atypical mitotic shape, medium to high nuclear grade, and $\geq 5$ mitotic shape/50 visual field. ${ }^{8}$

\section{CASE ILLUSTRATION}

We reported a case of 47-year old woman that came with a consistent pain on her left ring finger since 3 years prior to hospital admission. Initially, the patient felt an intermittent tingling sensation on the tip of her left ring finger, but the patient chose to ignore it since it was mild and no other symptoms felt. A year after, the tingling worsened and pain started to occur, especially when her finger was touched. Over time, the pain became more severe and tingling sensation was constantly felt. There was no history of trauma.

No abnormality were found on general physical examination. On local examination of her distal ring finger, there was no swelling, redness, deformity, nor mass, and the skin also intact with same color as the surroundings. The nail also had a normal appearance. There were pain over a light touch with visual analog scale (VAS) of 5. Paraesthesia at distal phalanx was also reported. The capillary refill time was less than 2 seconds. Flexion and extension movements of DIP and PIP joints were normal.

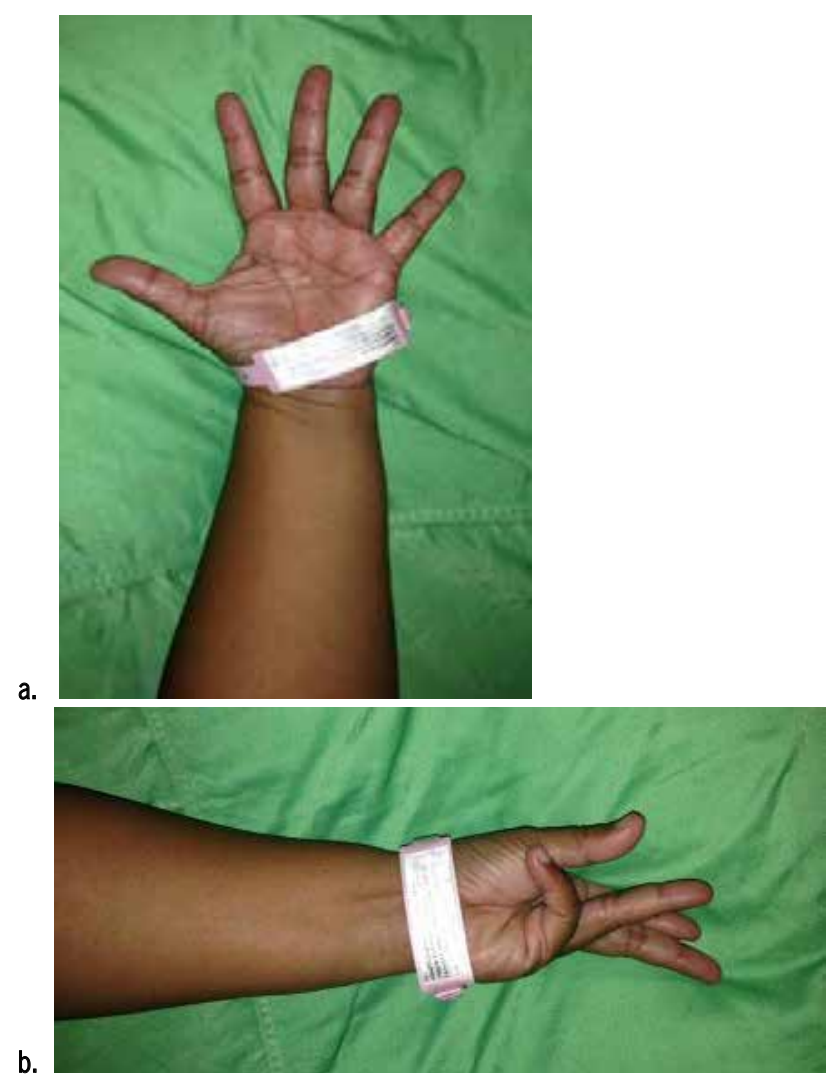

Figure 1: Pre-surgery clinical finding; normal appearance of left ring finger.

Plain radiograph of her left hand on anteroposterior and lateral projection showed no abnormality in her ring finger.

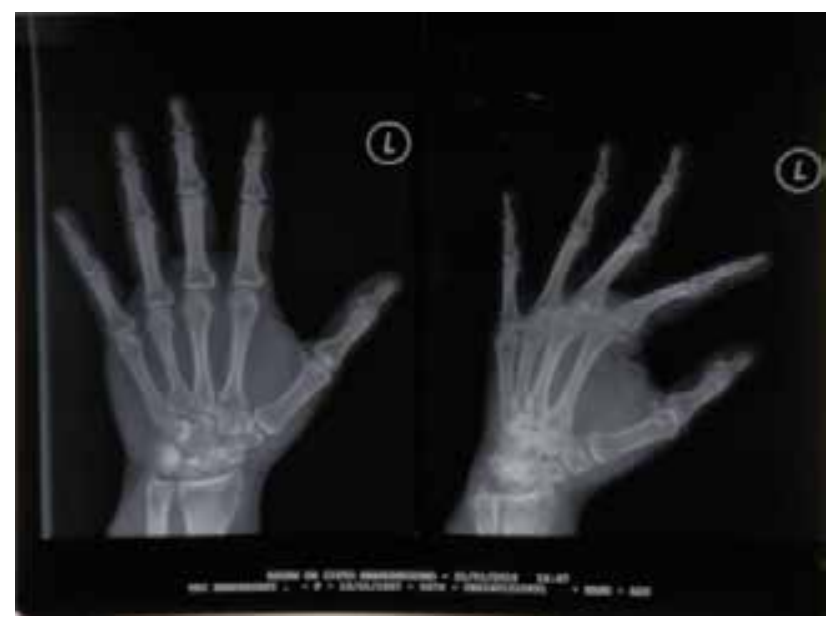

Figure 2: X-ray of left hand; normal appearance of bone and soft tissue of left ring finger. 
We diagnosed the patient with benign tumor on soft tissue of left ring finger with an initial differential diagnosis of fibroma, glomus tumor, and neuroma. To confirm the diagnosis, we performed tumor excisional biopsy to the patient. and found, macroscopic tissue with fibrous cap on the ulnar side of ring finger. Despite its location was on a close proximity to interdigital nerve, complete excisional biopsy was achieved.

a.

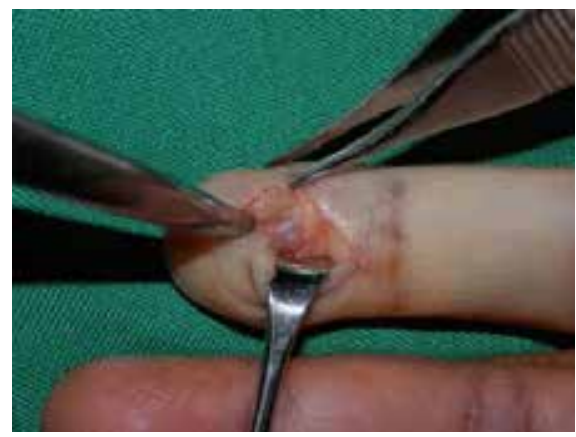

b.

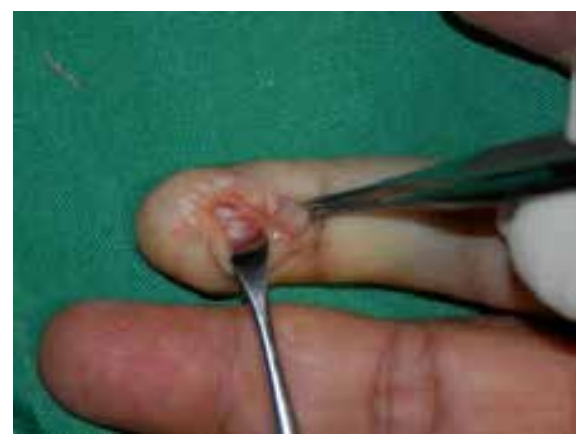

c.

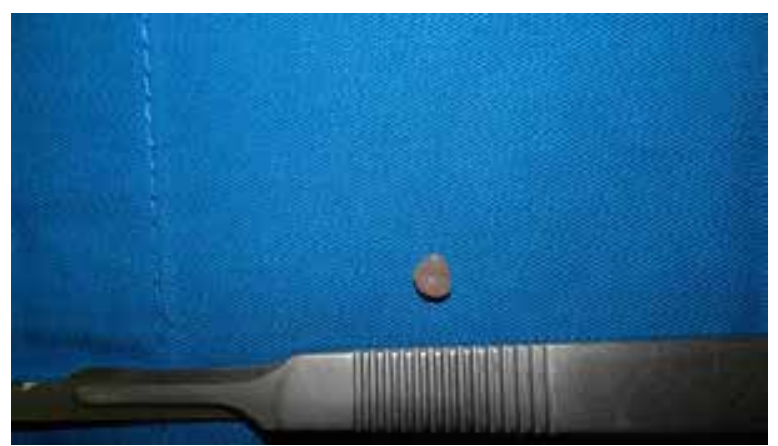

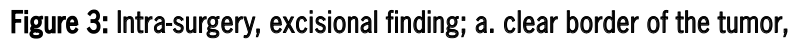
b. Complete excisional biopsy with clear margin, c. macroscopic appearance of the tumor with its capsule.

Histopathology finding showed a well-defined lesion surrounded by fibrous cap that consisted of several thin-walled vascular spaces that stretched and surrounded by layers of glomus cells. This findings corresponded with glomus tumor. a.

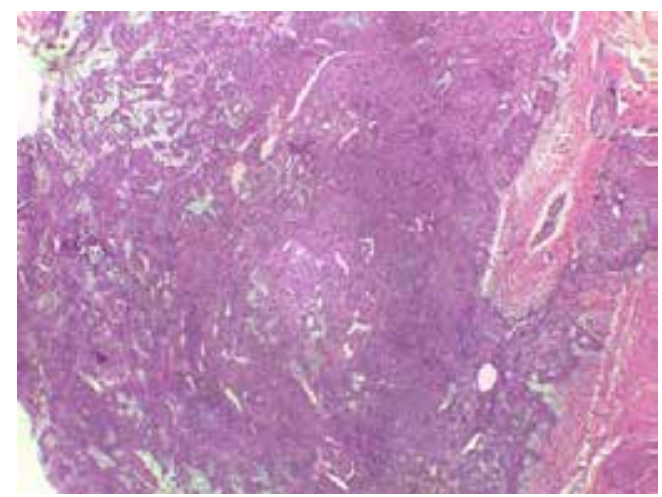

b.

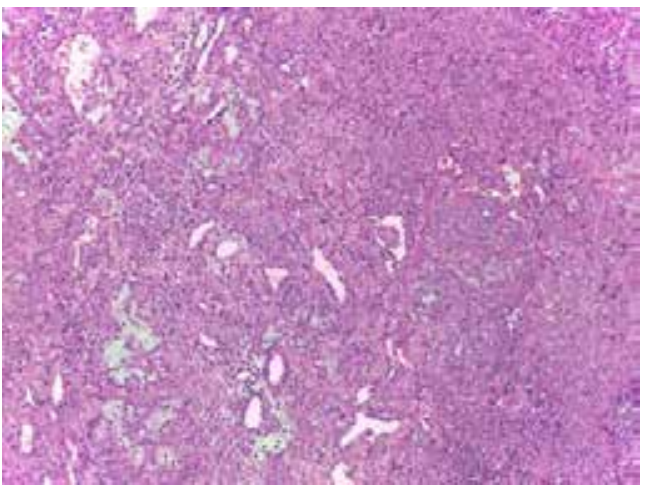

c.

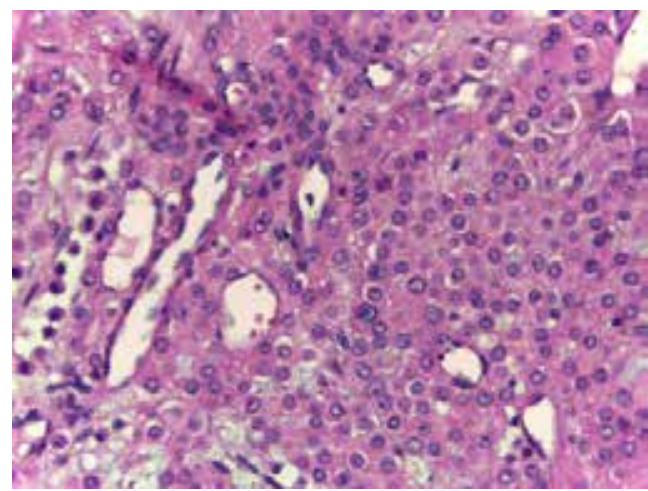

d.

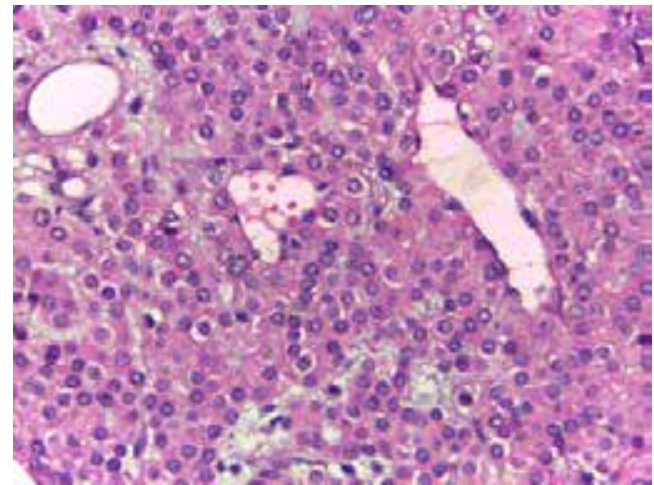

Figure 4: Histopathology finding; well-defined lesion surround by fibrous cap consisted of several thin-walled vascular spaces that stretched and surrounded by layers of glomus cells. 
One week after surgery, patient came to outpatient clinic with good surgical wound and no sign of infection. Patient felt that the pain and paraesthesia has decreased significantly. At the latest follow up, patient admitted that pain and paraesthesia had fully subsided. There were no complication nor recurrence was detected clinically.

\section{DISCUSSION}

Glomus tumor may appear as single or multiple lesions. It is more commonly found in subungual area on female, and non-subungual area on male. Clinically, glomus tumor are more prevalent on women aged 30-40 years old and is described as painful subcutaneous nodule. Glomus body hold a central role in thermoregulation, thus it is understandable why in the majority of the cases hypersensitivity towards temperature change can be found, especially against cold. Even though the most common predilection of glomus tumor is in subungual region, it can appear in any part of the body. ${ }^{6}$

In this case, the only clinical finding that supported the diagnosis toward glomus tumor was merely the pain in tip of left ring finger that had been worsening over time, along with its hypersensitivity to light touch, and accompanied with paraesthesia. The location of the tumor itself was not in subungual region, and no superficial bump was found. Glomus tumor is found subungually for $50 \%$ cases $^{11}$, so it is still possible diagnosis of this case. However, in a case reported by Wolfstein et $\mathrm{al}^{9}$, it was hypothesed that tumor histologic type, instead of its location, was more likely to be correlated with clinical findings.

Moreover, the other differential diagnoses were less likely to support the diagnosis. Fibroma is usually asymptomatic, unless it has grown in size that it compresses surrounding structures in the distal phalanx. Without any history of trauma, neuroma was also unlikely due to the very rare occurrence of spontaneous neuroma.

We also consider neither ultrasound nor MRI was necessarily performed due to benign characteristic found clinically. Another important characteristic of benign tumor, it has a well-defined border encapsulated with its capsule. Thus, we were confident to perform excisional biopsy directly.

Folpe et $a^{10}$ classified glomus tumor into four histological class: malignant glomus tumor, simplastic glomus tumor, potentially-malignant glomus tumor, and glomangiomatosis. For this particular case, the microscopic findings showed a well-defined lesion surrounded by fibrous cap that consisted of several thin-walled vascular spaces that stretched and surrounded by layers of glomus cells, which suited the description for simplastic glomus tumor, the benign one. And this diagnosis is suitable with its clinical findings.

\section{CONCLUSION}

Glomus Tumor is a rare occurrence and diagnosis can be determined solely by clinical findings. Supporting diagnostic modalities, such as ultrasound or MRI, may be performed when there is suspicion of multiple tumor or malignancy. Excisional biopsy is the definitive treatment and gold standard diagnostic modality for Glomus Tumor.

\section{ACKNOWLEDGEMENT}

Author would like to thanks the Department of Orthopaedic and Traumatology, Faculty of Medicine, University Indonesia, Cipto Mangunkusumo Hospital for the support for this case.

\section{REFERENCES}

1. Song M, Ko HC, Kwon KS, Kim MB. Surgical treatment of subungual glomus tumor: a unique and simple method. Dermatol Surg. 2009;35(5):786-91.

2. Chen SH, Chen YL, Cheng MH, Yeow KM, Chen HC, Wei FC. The use of ultrasonography in preoperative localization of digital glomus tumors. Plast Reconst Surg. 2003;112(1):115-9

3. Al-Qattan MM, Al-Namla A, Al-Thunayan A, Al-Subhi F, ElShayeb AF. Magnetic resonance imaging in the diagnosis of glomus tumours of the hand. J Hand Surg Br. 2005;30(5):53540.

4. Pahwa M, Pahwa P, Kathuria S. Glomus tumour of the nail bed treated with the 'trap door' technique: a report of two patients. J Dermatolog Treat. 2010;21(5):298-300.

5. Anakwe RE, McEachan JE. A glomus tumour beneath the painful unpolished nail. Canadian Medical Association Journal. 2010;182(12): 1329.

6. Peretz E, Grunwald MH, Avinoach I, Halevy S. Solitary glomus tumour. Australas J Dermatol. 1999;40(4):226-7.

7. Brathwaite CD, Poppiti RJ, Jr. Malignant glomus tumor. A case report of widespread metastases in a patient with multiple glomus body hamartomas. Am J Surg Pathol. $1996 ; 20(2): 233-8$ 
8. Terada T, Fujimoto J, Shirakashi Y, Kamo M, Sugiura M. Malignant glomus tumor of the palm: a case report. J Cutan Pathol. 2011;38(4):381-4.

9. Wollstein A, Wollstein R. Subungual glomangiomyoma - a case report. Hand Surg. 2012;17(2):271-3.

10. Folpe AL, Fanburg-Smith JC, Miettinen M, Weiss SW. Atypical and malignant glomus tumors: analysis of 52 cases, with a proposal for the reclassification of glomus tumors. Am J Surg Pathol. 2001;25(1):1-12.
11. Sommer NZ, Brown RE. The perionychium. In: Wolfe SW, Hotchkiss RN, Pederson WC, Kozin SH, editors. Green's operative hand surgery. Philadelphia: Elsevier; 2011. p. 34950. 